\title{
Flexibility in Coping with Stress Questionnaire: structure and psychometric properties
}

\author{
Matgorzata A. Basińska (1D A,B,D,E,F, Agnieszka Kruczek (D) ${ }^{B, D, E, F}$, Agata Borzyszkowska (D) ${ }^{B, E, F,}$ \\ Katarzyna Góralska $\mathbb{( D D}^{B, F}$, Izabela Grzankowska (D) ${ }^{B, E, F}$, Michalina Sottys $\mathbb{D}^{C, D, E}$ \\ Faculty of Psychology, Kazimierz Wielki University, Bydgoszcz, Poland
}

\section{BACKGROUND}

Flexibility in coping relies on applying a coping strategy that is appropriate to the circumstances. Individuals who are flexible in coping exhibit sensitivity to subtle signals sent by the environment. Therefore, they are able to adjust their behaviour accordingly and function in a more adaptive manner.

\section{PARTICIPANTS AND PROCEDURE}

The study included $N=1535$ participants. The following methods were used: the Flexibility in Coping with Stress Questionnaire (FCSQ-14) and the Cognitive Flexibility Inventory $(\mathrm{CFI})$.

\section{RESULTS}

The Flexibility in Coping with Stress Questionnaire measures flexibility as a feature of the process of coping with which an individual applies coping strategies. The Flexibility in Coping with Stress Questionnaire is an accurate and reliable method of measuring coping flexibility and three of its subscales: the Repertoire of coping strategies, the Changeability of their use, and Reflexivity.

\section{CONCLUSIONS}

The Flexibility in Coping with Stress Questionnaire examines three subscales of flexibility, namely, Repertoire of coping strategies, Changeability, and Reflexivity. This measurement is accurate and reliable. The questionnaire is applied to the study of persons exposed to severe or chronic stress at work, when we want to assess the individual's ability to change their functioning in a stressful situation. It can be used to examine healthy and somatically ill people, in the area of research and clinical diagnosis.

\section{KEY WORDS}

flexibility in coping; Flexibility in Coping with Stress Questionnaire (FCSQ-14); multistudy report; high-risk professionals

CORResPonding Author - Agnieszka Kruczek, Ph.D., Faculty of Psychology, Kazimierz Wielki University, 1 Staffa Str.,

85-867 Bydgoszcz, Poland, e-mail: agnieszka_kruczek@ukw.edu.pl

AUthors' CONTRIBUtion - A: Study design - B: Data collection - C: Statistical analysis - D: Data interpretation .

E: Manuscript preparation $\cdot F$ : Literature search $\cdot$ G: Funds collection

to Cite this ARTICle - Basińska, M. A., Kruczek, A., Borzyszkowska, A., Góralska, K., Grzankowska, I., \& Sołtys. M.

(2021). Flexibility in Coping with Stress Questionnaire: structure and psychometric properties. Current Issues in

Personality Psychology, 9(2), 179-194.

RECEIVED 14.09.2020 · REVIEWED 05.02.2021 · ACCEPTED 17.05.2021 · PUBLISHED 21.06.2021 


\section{BACKGROUND}

The results of our previous research which concerned the Polish adaptation of the Coping Flexibility Scale by Kato (2012, 2014, 2015; Basińska, 2015) showed that two complementary subscales of coping flexibility - evaluation and adaptive coping - are perceived differently in the Polish and Japanese sample and thus in different cultural circles. Kato (2012, 2014, 2015) captures evaluation coping as an ability to discontinue ineffective actions, whereas adaptive coping was defined as the ability to develop and implement new, alternative coping strategies. According to our previous research results, participants in a Polish sample seem to identify evaluation coping only as a mental activity and adaptive coping as acting (Basińska, 2015; Grzankowska \& Minda, 2015; Kruczek, 2015). This was the basis of our thinking about creating our own scale for measuring flexibility in coping, which would be adapted to Polish sociocultural conditions.

\section{THEORETICAL BACKGROUND FOR THE FLEXIBILITY IN COPING WITH STRESS QUESTIONNAIRE (FCSQ-14)}

Under the transactional model of stress, actions undertaken in order to cope with a stressful situation are defined as a constant shift of cognitive and behavioural efforts to manage specific external and/or internal demands that are appraised as taxing or exceeding the resources of the person (Lazarus, 1993). This approach to coping assumes that it is a process, and its purpose is to manage stress effectively. Both these aspects were covered by Lazarus and Folkman (1984) in their model of stress and coping. They identified three types of appraisal which follow one another, in line with the dynamics of a stress transaction. Two of the appraisals are commonly known - primary and secondary - as these are frequently discussed in the field literature. However, Lazarus and Folkman (1984, p. 38) also identified the type known as reappraisal, which plays a particularly important role from the point of view of coping understood as a process directed towards effective stress management. The individual in a difficult situation first evaluates whether it is stressful or not (primary appraisal), then appraises their own coping resources (secondary appraisal), and after using these the individual evaluates the efficacy of the adopted strategy (reappraisal) and determines whether the stressful situation still exists or has been successfully resolved. If the problem still exists, then the subsequent appraisal proceeds in the same manner as the primary appraisal, and the situation is appraised again to assess its difficulty and the individual's ability to cope with it. Therefore, the role of reappraisal might have been underestimated because the authors themselves acknowledged that it did not differ in its essence from the primary appraisal but only occurs at a different point in the coping process. This aspect related to the evaluation of the efficiency of coping strategies was emphasised by Kato (2001) and Cheng (2001). They explicitly underlined the aspect of the efficiency of the coping process and emphasised the conditions which lead to its successful resolution. The individual's ability to change their coping strategies was defined as coping flexibility. According to Cheng (2003), flexibility is reflected in the individual's tendency to use a variety of strategies in order to meet specific demands of various stressful situations.

In some cases, even if there are no changes in external circumstances, the individual decides to change their strategies as a result of having evaluated the previously adopted strategy as ineffective. Flexibility, in this sense, is the individual's willingness to attentively monitor the effects of their coping strategies and to change them immediately if they appear to be ineffective (Kato, 2001, 2012, 2015). Kato (2001, 2015) argued that coping flexibility includes two processes, i.e., evaluation coping and adaptive coping (Brandtstädter \& Renner, 1990). During the process of appraisal, the individual assesses the efficiency of the strategies that were used and considers the possibility of abandoning them if the appraisal is negative. The process has a similar function to reappraisal in Lazarus and Folkman's theory (1984). According to Kato, the process of adaptation consists of the ability to produce and implement a new coping strategy in place of an ineffective coping strategy. This clearly suggests that these two processes have both cognitive and behavioural aspects. There is no change in behaviour without cognitive flexibility, as it is a crucial aspect of flexible coping (Cheng, 2001) because it involves the elements of primary appraisal, secondary appraisal and reappraisal, as identified by Lazarus and Folkman (1980, 1984).

This approach to coping flexibility assumes the individual's ability to think critically and creatively. Critical assessment skills are particularly essential at the evaluation stage, while creative thinking is vital for adaptive coping. Vriezekolk et al. (2012) emphasised the key significance of these aspects for coping flexibility and extended the definition of coping flexibility proposed by other researchers (Brandtstädter \& Renner, 1990; Cheng, 2001). The individual's willingness to attentively monitor the effects of their actions and to examine their coping assumes a certain level of reflexivity (Vriezekolk et al., 2012). The ability to reflect one's actions in a critical way is important for ultimately abandoning any ineffective strategies.

It is vital to note that a prerequisite for flexible coping is to have a relatively wide range of coping strategies at one's disposal. The individual who does not have many coping strategies in their coping repertoire will not be able to change their behaviour even if they notice that the strategies applied are ineffective. 
The individual's belief that they have a wide range of available coping strategies reflects their self-trust and confidence in having a variety of resources and competences for coping with various circumstances, and in the ability to use all the resources effectively to cope with stress (Southward, 2014).

In their theory, Lazarus and Folkman (1984) emphasised that coping strategies varied in response to changes in situation (inter-situational changeability). Kato $(2012,2015)$, on the other hand, referred to the theory of dual process to argue for intra-situational changeability, that is a shift in coping strategies without any change in situation, but on account of their ineffectiveness (criteria of coping efficiency). However, the concept construct of flexible coping suggested by Kato is not sufficiently supported by statistical data in studies conducted among Western culture populations (Basińska, 2015; Jones, 2015; Southward, 2014). Therefore, a decision was taken, based on the aforementioned theories, that flexibility in coping should be approached much more broadly, taking into account all the aspects suggested by research findings. Firstly, flexibility in coping requires that the individual possesses a relatively wide array of coping strategies. Secondly, flexibility in coping assumes changeability - defined by Lazarus and Folkman (1984) as cross-situational changeability, that is the adoption of various coping strategies appropriately to shifting situational conditions - and inter-situational changeability that was discussed by Kato (2015) and is related to the choice of coping strategies in line with changes in the perception of a stressful situation, i.e., the strategy might also be modified when objective circumstances have not changed. Thirdly, flexibility manifests itself through a reflective evaluation of one's own behaviour to achieve specific goals and possibly to correct one's behaviour (using assimilation and accommodation processes), as suggested by Vriezekolk et al. (2012).

It is important to emphasise that flexibility in coping is a trait characteristic of the coping process and of the manner in which the individual uses coping strategies. Previous research (Basińska et al., 2015; Janicka, 2015; Kruczek, 2015; Piórowska \& Banasik, 2015; Sołtys, 2015) indicates its relation with individual resources, and given its consequences (Kato, 2012; Vowles et al., 2014), it might be considered an individual resource itself. However, when discussing the significance of flexibility in coping, it is important to consider one more perspective, i.e., executive functions.

\section{THE HISTORY OF RESEARCH INTO FLEXIBLE COPING - AN OVERVIEW OF RESEARCH TOOLS}

The field literature provides several questionnaires designed to assess flexible coping. These questionnaires are presented below chronologically.
The Flexible Goal Adjustment Scale (FGAS) by Brandtstädter and Renner (1990) is used to assess individual differences in the ability to modify coping goals in a changing environment. Coping is approached from the perspective of two tendencies: assimilation, i.e., seeking to change one's development conditions in accordance with one's personal preferences (Tenacious Goal Pursuit subscale, TGP); and accommodation that denotes the adjustment of personal preferences to situational limits (Flexible Goal Adjustment subscale, FGA). The results of research using this scale show that it has some deficiencies, e.g. it fails to adequately distinguish between FGA and TGP (Henselman et al., 2011). Also, a large part of the of variance in the TGP and FGA item scores was explained by the item-keying factors rather than by the target factors. The target factors that were measured by the TGP and FGA items showed the same directional relation with happiness and selfacceptance and no relationship with each other. Neither TGP nor FGA was related to age (Cheng et al., 2014).

The Coping Flexibility Questionnaire (CFQ) by Cheng (2001) is an open measurement tool based on situational factors. It measures how respondents evaluate the characteristics of a situation and evaluates their responses to a series of stressful events. Flexible coping is expressed in the form of an individual coping profile, which indicates the frequency of using various strategies applied in stressful situations. The scale recognises coping as reduced to the discontinuation of ineffective coping strategies and implementation of alternative strategies. Findings have shown differences in the use of coping strategies according to cultural circles. Cross-cultural studies (Peng \& Nisbett, 1999) have shown differences in the perceptual style between Chinese and American students. It could be possible that the Chinese may be more sensitive to situational changes and more flexible in their perceptual patterns than their American counterparts are (Cheng et al., 1999). Whereas Americans tend to use more behavioural coping, Asians tend to use more cognitive coping. Taken together, the cognitive and coping patterns may be different for Western samples.

The Perceived Ability to Cope with Trauma (PACT) by Bonanno et al. (2011) evaluates how plans and ideas are generated and revised. It measures how flexible respondents are in their implementation of strategies designed to process trauma (trauma focus) and to move beyond the trauma (forward focus). Bonanno et al. (2011) developed a flexible coping score by aggregating standardised results from the two subscales, calculating the divergences between subscale results and subtracting the sum of points from the result of the divergence. The scale captures flexibility in the specific context of coping with potentially traumatic life events, but is limited to trauma focus. 
The Coping Flexibility Scale (CFS) by Kato (2012) is based on the dual-process model of coping flexibility by Brandtstädter and Renner. It consists of 10 items which, similarly to Cheng's method (2001), make up two subscales: Evaluation coping and Adaptive coping. Previous research results showed that the CFS is susceptible to cultural influences. The adaptive research results for the CFS (Basińska, 2015) indicated that respondents from the Polish sample did not distinguish between the two subscales, unlike those from the Japanese sample. This might be related to the diverse cultural backgrounds of respondents and consequently their different understanding of evaluation coping and adaptive coping.

The Coping Flexibility Questionnaire (COFLEX) by Vriezekolk et al. (2012) consists of 13 items. Based on a factor analysis, it produced a two-factor model of coping flexibility with acceptable internal consistency: versatility, the capability of switching between assimilative and accommodative coping strategies according to personal goals and situational demands; and reflective coping, the capability of generating and considering coping options, and evaluating the suitability of a coping strategy in a given situation (Vriezekolk et al., 2012). The weak point of COFLEX is that the development and item selection of the questionnaire was guided by theory and done by experts and researchers using feedback from patients instead of using qualitative techniques to let the patients yield items. Also, the authors suggested that there was preliminary evidence of the validity of the versatility dimension, while the validity of reflective coping could not be firmly established.

The above overview shows that none of the existing questionnaires for examining flexibility has covered all of its manifestations. Therefore, it seemed advisable to develop a new method.

\section{WORK ON DEVELOPING THE FLEXIBILITY IN COPING WITH STRESS QUESTIONNAIRE (FCSQ-14)}

Efforts aimed at the development of a questionnaire to measure flexibility in coping were undertaken in response to the partially unsatisfactory results of the Polish adaptation of the Coping Flexibility Scale by Kato (Basińska, 2015; Sołtys, 2015), which was also not reflected in studies conducted in other Western culture populations (Jones, 2015; Southward, 2014). In order to design a tool that adequately operationalises all the key aspects of flexibility in coping, a team of experts including eight research psychologists generated an initial pool of 49 statements based on the theoretical approaches presented in this article.

The aims of the conducted psychometric procedure were particularly: (1) to estimate the content validity ratio for each item; (2) to perform a reliability analysis; (3) to evaluate the internal structure of the constructed tool (exploratory factor analysis [EFA], subscale intercorrelations) and confirm the structure in view of theoretical assumptions (CFA); (4) to analyse intergroup differences; (5) to estimate external validity; (6) to perform normalisation.

\section{PARTICIPANTS AND PROCEDURE}

\section{PILOT STUDY}

\section{PARTICIPANTS}

The participants were 230 people - 145 women (63\%) and 85 men (37\%), with an average age of 35 years $(S D=13.11)$; age range: $18-70$. Respondents belonged to two different educational groups: those with secondary education $(n=127,55 \%)$ and those with higher education $(n=103,45 \%)$.

\section{STUDY QUESTIONNAIRES}

Demographics. The requested demographic information consisted of sex, age, education.

Flexibility in Coping with Stress Questionnaire (FCSQ-14) - trial version.

\section{ANALYSIS}

Following a pilot study, these statements underwent a thorough psychometric analysis. First of all, four items with the lowest discriminating power were rejected and the competent judge assessment was implemented. The task of the team of judges (consisting of five psychologists) was to assess theoretical accuracy of statements on the scale from 0 to 4 (where 0 meant a fully inadequate statement and 4 meant a fully adequate statement). The assessment was carried out on the basis of four categories: comprehensiveness of applied coping methods, an ability to change the strategy when the situation does not change (intra-situational changeability), generation of the most effective coping strategies (inter-situational changeability), and evaluation of the coping process. The content validity ratio (CVR) was calculated for each item (Hornowska, 2001). A total of 35 statements remained.

Next, the EFA was performed to test the 4-factor solution. On the basis of the results of a series of a few dozen analyses, items with the lowest factor loadings (EFA) were successively removed. EFA analyses showed that the three-factor solution is the most adequate (factor 1 - Changeability; factor 2 - Repertoire; factor 3 - Reflectivity). Intra- and inter-situational variability was not represented by separate factors. 
The three-factor solutions ${ }^{1}$ accounted for $61.47 \%$ of variance: factor 1 (Changeability) - 45.73\%, factor 2 (Repertoire) $-8.43 \%$, and factor 3 (Reflexivity).

Then, after a critical, qualitative analysis of the remaining 17 statements, the research team decided to reject one ambiguous_item, and to eliminate one linguistically complex item due to a potential difficulty a respondent could have with understanding it, as well as to reduce the disproportion in the number of items representing each factor. It was also decided to remove one negative item, which showed the lowest correlation with items remaining in the subscale describing the versatility of the strategy repertoire and which had the lowest factor loading.

\section{SECOND STUDY}

\section{PARTICIPANTS}

A study aimed at developing and determining the psychometric properties of the questionnaire was conducted in 2017 in seven groups of adults, including four clinical groups (cardiac patients, gastric patients, oncological patients and alcohol-abusing patients), two high-risk occupational groups (nurses and officers of the state fire service), and among healthy adults ${ }^{2}$. The inclusion criterion for the clinical group was medical diagnosis, and the exclusion criterion was cognitive impairment; therefore persons over 70 years of age were excluded from the study. The socio-demographic characteristics of the studied groups are presented in Table 1.

\section{STUDY QUESTIONNAIRES}

Demographics. The requested demographic information consisted of sex and age.
Flexibility in Coping with Stress Questionnaire (FCSQ-14) - final version. The scale measures the ability to change coping strategies depending on the situation (inter-situational changeability) and the use of various strategies in a single transaction (intra-situational changeability). Ultimately, the questionnaire consists of 14 statements which are assessed by respondents by way of selecting one of the responses: 0 (never), 1 (sometimes), 2 (often), or 3 (always). The higher the score, the more flexible the respondent is in their coping. The questionnaire consists of three subscales.

In the version for adults, the following scales have been extracted: Repertoire, Changeability and Reflexivity. The version for young people (14 to 19 years old, or, in the case of secondary school education ${ }_{2}$ up to 20 years old) has the following subscales: Changeability, Coping competencies, and Reflexivity. The results of those analyses were presented elsewhere (Grzankowska et al., 2019).

In the adult version, when a respondent scores high on the Repertoire scale (statements 1, 3, 6, 10,13) they are considered to have a broad repertoire of strategies for dealing with stress and to be able to find adequate or new coping strategies and apply them when necessary, i.e., when new difficulties arise, they perceive themselves as competent in dealing with stress.

When a respondent scores high on the Changeability scale (statements $4,5,7,8,11,14$ ), then they are willing to use coping strategies that will ensure effective stress management. When they notice that the method used is ineffective, they change it. They are ready to search for the right way to cope and to use various strategies, both psychological and behavioural, interchangeably to deal with stress.

When a respondent scores high on the Reflexivity scale (statements $2,9,12$ ), they are willing to give themselves some time to consider their coping strategies. The individual reflects on their strategies

\section{Table 1}

Socio-demographic characteristics of respondents $(N=1535)$

\begin{tabular}{lccccccc}
\hline Study group & $n$ & \multicolumn{3}{c}{ Sex } & \multicolumn{3}{c}{ Age } \\
\cline { 3 - 8 } & & $\begin{array}{c}\text { Female } \\
f / \%\end{array}$ & $\begin{array}{c}\text { Male } \\
f / \%\end{array}$ & $M$ & $S D$ & Min & Max \\
\hline Gastric patients & 100 & $46(46 \%)$ & $54(54 \%)$ & 32.52 & 11.23 & 17 & 69 \\
Cardiac patients & 112 & $44(39 \%)$ & $68(61 \%)$ & 55.72 & 8.27 & 29 & 70 \\
Cancer patients & 110 & $64(58 \%)$ & $46(42 \%)$ & 56.75 & 10.16 & 23 & 70 \\
Alcohol addicts & 114 & $36(32 \%)$ & $78(68 \%)$ & 44.80 & 14.14 & 18 & 69 \\
Firefighters & 165 & $164(99.4 \%)$ & $1(0.6 \%)$ & 35.31 & 6.90 & 19 & 50 \\
Nurses & 280 & $271(97 \%)$ & $9(3 \%)$ & 39.52 & 10.61 & 21 & 66 \\
Healthy controls & 654 & $134(20 \%)$ & $520(80 \%)$ & 34.76 & 13.68 & 21 & 70 \\
\hline
\end{tabular}


in terms of values and objectives that they view as important and is able to accept this situation.

Cognitive Flexibility Inventory (CFI) by Dennis and Vander Wal (2010) as adapted into Polish by Piórowski et al. (2017). The questionnaire measures two aspects of cognitive flexibility: the ability to perceive and generate many alternative solutions (Alternatives subscale), and a tendency to perceive difficult situations as controllable (Control subscale). It was assumed that the results obtained in both questionnaires would be moderately correlated with each other, and the relationships observed between the scale of alternatives and the scale of variation would be the strongest.

\section{STATISTICAL ANALYSIS}

All analyses were performed using IBM SPSS Statistics. The statistical significance threshold was assumed to be $p<.05$. The normality of variable distributions was checked and adequate analyses were used. All subscales had acceptable Cronbach's $\alpha$ coefficients. A bivariate correlation was deemed small, moderate or large when the respective $r$ value was $.30, .30-.49$, or .50 .

\section{RESULTS}

\section{FLEXIBILITY IN COPING SCORES DISTRIBUTION}

Table 2 shows the distribution of coping scores (including subscales) obtained from each respondent sample (excluding missing data and outliers). Due to formal limitations related to the length of the article, the following tables and further analyses present the aggregate results of somatically ill patients $(n=318)$, high-risk professionals $(n=439)$, healthy adults $(n=654)$, and an additional combination of the latter two non-clinical groups $(n=1093)$.

The results showed that people addicted to alcohol have on average the lowest flexibility in coping, both overall and in specific dimensions. Representatives of high-risk occupations, on the other hand, appear to be the most flexible group.

The asymmetry and dispersion measurements obtained in the study, not exceeding the absolute value of 1 (Table 2), indicate that the distribution of variables in the subgroups is close to normal and, in line with the central limit theorem, parametric statistics can be applied.

\section{RELIABILITY OF THE FCSQ-14}

The reliability of the FCSQ-14 was determined using two methods: internal consistency and test-retest reliability.
Internal consistency of the FCSQ-14. The internal consistency for the overall result of the FCSQ-14 and its subscales was calculated using Cronbach's $\alpha$. Table 3 presents values of the coefficient calculated separately for each of the studied groups.

In all the groups Cronbach's $\alpha$ for the overall result was high, ranging from .91 to .94. For the Repertoire subscale, Cronbach's $\alpha$ values ranged from .81 to .88 , and for the Changeability subscale from .88 to .92 , which indicates their satisfactory reliability. For the Reflexivity subscale, relatively satisfactory values of Cronbach's $\alpha$ were recorded in the group of somatically ill persons (.70) and alcohol addicts (.67). In the group of healthy controls and in the group of high-risk professionals, these values were lower. The lower values of internal consistency for this subscale, as compared to other subscales, can be explained by the fact that it comprises only three items ${ }^{3}$. Moreover, in non-clinical groups, the lower consistency of the Reflexivity subscale results from a poorer correlation of item 2 with other items. In clinical trials, the discriminating power of individual Reflexivity items is higher, suggesting that this dimension in flexibility in coping is particularly differentiating in difficult situations related to chronic stress. Nevertheless, any conclusion about the Reflexivity level should be drawn with caution in the study of healthy controls, especially when it is an element of the individual's assessment.

Test-retest reliability of the FCSQ-14. A total of 60 students were examined in the first and second measurements. However, due to the fact that in the second survey, 31 questionnaires had gaps, only 29 were analysed. Reproducibility was evaluated on the basis of the results of 29 students (22 females, 7 males), age range: $19-23\left(M_{\text {age }}=21.76, S D=0.97\right)$. The interval between the first and second FCSQ-14 measurements was 8 weeks. The results of Pearson correlation are presented in Table 4 .

Test-retest results indicate satisfactory reproducibility over time for the Repertoire subscale and general flexibility in coping. A moderate correlation between the Changeability and Reflexivity subscales suggests that these dimensions of flexibility in coping might vary more over time (compared to the overall range of coping strategies available to the individual) and may depend on situational factors (Jankowski \& Zajenkowski, 2009). The relatively low correlation coefficient obtained for the Reflexivity subscale may also result from its low internal consistency.

\section{VALIDITY OF THE FCSQ-14}

For FCSQ-14 validation, the following methods of theoretical accuracy assessment were applied: factor analysis (exploratory and confirmatory), intercorrelation analysis, analysis of differences between 
M. A. Basińska, A. Kruczek, A. Borzyszkowska, K. Góralska, I. Grzankowska, M. Sołtys

Table 2

Distribution parameters of overall results for the FCSQ-14 and its subscales $(N=1525)$

\begin{tabular}{|c|c|c|c|c|c|c|}
\hline Study group & M & $S D$ & Min & Max & Skew & $\mathrm{KU}$ \\
\hline \multicolumn{7}{|c|}{ Flexibility in coping - overall score } \\
\hline Somatically ill persons & 23.05 & 9.09 & 0 & 42 & .09 & -.16 \\
\hline Alcohol addicts & 22.36 & 8.69 & 1 & 42 & 0 & -.34 \\
\hline $\begin{array}{l}\text { Representatives of high-risk } \\
\text { professions }\end{array}$ & 25.04 & 7.12 & 6 & 42 & .06 & -.23 \\
\hline Healthy controls & 23.85 & 7.78 & 2 & 42 & .02 & -.31 \\
\hline Non-clinical group - total & 24.32 & 7.54 & 2 & 42 & .01 & -.26 \\
\hline \multicolumn{7}{|c|}{ Repertoire subscale } \\
\hline Somatically ill persons & 8.02 & 9.09 & 0 & 42 & .09 & -.16 \\
\hline Alcohol addicts & 7.86 & 8.69 & 1 & 42 & 0 & -.34 \\
\hline $\begin{array}{l}\text { Representatives of high-risk } \\
\text { professions }\end{array}$ & 8.94 & 7.12 & 6 & 42 & .06 & -.23 \\
\hline Healthy controls & 8.10 & 7.78 & 2 & 42 & .02 & -.31 \\
\hline Non-clinical group - total & 8.44 & 7.54 & 2 & 42 & .01 & -.26 \\
\hline \multicolumn{7}{|c|}{ Changeability subscale } \\
\hline Somatically ill persons & 9.74 & 4.27 & 0 & 18 & .07 & -.33 \\
\hline Alcohol addicts & 9.49 & 3.99 & 0 & 18 & .05 & -.53 \\
\hline $\begin{array}{l}\text { Representatives of high-risk } \\
\text { professions }\end{array}$ & 10.95 & 3.48 & 2 & 18 & -.06 & -.19 \\
\hline Healthy controls & 10.32 & 3.83 & 0 & 18 & .07 & -.35 \\
\hline Non-clinical group - total & 10.57 & 3.70 & 0 & 18 & .01 & -.30 \\
\hline \multicolumn{7}{|c|}{ Reflexivity subscale } \\
\hline Somatically ill persons & 5.30 & 2.03 & 0 & 9 & -.03 & -.19 \\
\hline Alcohol addicts & 5.01 & 1.94 & 0 & 9 & -.10 & -.35 \\
\hline $\begin{array}{l}\text { Representatives of high-risk } \\
\text { professions }\end{array}$ & 5.15 & 1.73 & 1 & 9 & .09 & -.24 \\
\hline Healthy controls & 5.43 & 1.85 & 0 & 9 & -.12 & -.22 \\
\hline Non-clinical group - total & 5.31 & 1.81 & 0 & 9 & -.03 & -.25 \\
\hline
\end{tabular}

Note. FCSQ-14 - Flexibility in Coping with Stress Questionnaire; Skew - skewness; KU - kurtosis.

groups, and a correlation coefficient analysis between the FCSQ-14 and other tests (external criterion). Item content accuracy was confirmed during pilot studies using the competent judges' assessment.

Internal validity. The internal (factorial) validity of the FCSQ-14 was examined in pilot studies. The sample consisted of 230 persons (55 men and 175 women), age range: $18-71\left(M_{\text {age }}=30.85, S D=12.42\right)$. The analysis made it possible to identify three factors for which eigenvalues were higher than 1 (Kaiser's criterion). In total, three factors accounted for $61.47 \%$ of variance: factor 1 (Changeability) $-45.73 \%$, fac- tor 2 (Repertoire) $-8.43 \%$, and factor 3 (Reflexivity) $7.32 \%$. Table 5 shows the factorial loadings for each of the items, grouped into three main categories. Their values were satisfactory and ranged from .58 to .80 .

During the EFA, the scree plot (Cattell's criterion) suggested a single-factor solution as an alternative. Therefore, at a later stage of the study, in order to verify the obtained structure, a confirmatory factor analysis (CFA) was performed for two samples: an extended non-clinical group $(n=1093)$ and a total of all clinical groups $(n=432)$. The model was estimated using the maximum likelihood (ML) method. 
Table 3

Internal consistency (Cronbach's $\alpha$ ) in the studied subgroups

\begin{tabular}{lcccc}
\hline Study group & Repertoire & Changeability & Reflexivity & FC \\
\hline Somatically ill persons & .88 & .92 & .67 & .94 \\
Alcohol addicts & .88 & .89 & .70 & .94 \\
Representatives of high-risk professions & .81 & .88 & .59 & .91 \\
Healthy controls & .83 & .89 & .52 & .91 \\
Non-clinical group - total & .83 & .88 & .54 & .91 \\
\hline Note. FC - flexibility in coping (overall result). & & & &
\end{tabular}

Table 4

Reproducibility measures for FCSQ-14 $(N=29)$

\begin{tabular}{lcc}
\hline FCSQ-14 subscales & $r$ & $p$ \\
\hline Repertoire & .77 & $<.001$ \\
Changeability & .58 & .001 \\
Reflexivity & .41 & .028 \\
Flexibility in coping & .70 & $<.001$ \\
(overall score) & & \\
\hline $\begin{array}{l}\text { Note. FCSQ-14 - Flexibility in Coping with Stress Questionnaire; } \\
r \text { - Pearson's correlation coefficients; } p \text { - significance level. }\end{array}$
\end{tabular}

The results of the CFA (for a 3-factor solution) conducted in a non-clinical group indicated that the model presented a moderate data fit, $d f=74$, $\chi^{2}=155.77, p<.001^{4}$, RMSEA $=.065,90 \%$ CI [.049, $.081]$, CFI $=.93$, IFI $=.92$, GFI $=.92$, AGFI $=.88$. On the other hand, the CFA carried out in the clinical group showed a slightly worse, but acceptable, data fit, $d f=74, \chi^{2}=244.98, p<.001$, RMSEA $=.080,90 \% \mathrm{CI}$ $[.069, .091], \mathrm{CFI}=.93, \mathrm{IFI}=.93, \mathrm{GFI}=.91, \mathrm{AGFI}=.87$. The results of the CFA (for a 3-factor solution) conducted in a clinical and non-clinical group (together) indicated that the model presented a moderate data fit, $d f=74, \chi^{2}=437.96, p<.001$, RMSEA $=.065,90 \% \mathrm{CI}$ $[.059, .071], \mathrm{CFI}=.93, \mathrm{IFI}=.91, \mathrm{GFI}=.95, \mathrm{AGFI}=.93$. An RMSEA less than or equal to 0.8 is considered to be a good fit of the model to the data (Schumacker \& Lomax, 2004).

To sum up, the three-factor structure that the FCSQ-14 obtained in the EFA was confirmed by results of the CFA in the non-clinical group (healthy controls) and clinical group 5 . The following graph shows the structure of the FCSQ-14 in the non-clinical group and the path values obtained in the CFA.

FCSQ-14 subscale correlations. The next method used for testing the theoretical validity of the FCSQ-14 was a correlation matrix analysis. Correlation coefficients between FCSQ-14 subscales were calculated separately for the non-clinical group
Table 5

Factor loadings for exploratory factor analysis with varimax rotation of the FCSQ-14

\begin{tabular}{|c|c|c|c|}
\hline \multirow[t]{2}{*}{ Items } & \multicolumn{3}{|c|}{ Factor loads } \\
\hline & $\begin{array}{c}\text { Factor } 1- \\
\text { Changeability }\end{array}$ & $\begin{array}{l}\text { Factor } 2 \text { - } \\
\text { Repertoire }\end{array}$ & $\begin{array}{l}\text { Factor } 3- \\
\text { Reflexivity }\end{array}$ \\
\hline 1 & .23 & .73 & .13 \\
\hline 2 & .17 & .01 & .69 \\
\hline 3 & .54 & .58 & .15 \\
\hline 4 & .79 & .27 & .04 \\
\hline 5 & .69 & .35 & .10 \\
\hline 6 & .25 & .76 & .23 \\
\hline 7 & .71 & .20 & .21 \\
\hline 8 & .58 & .30 & .24 \\
\hline 9 & .28 & .28 & .58 \\
\hline 10 & .35 & .69 & .10 \\
\hline 11 & .70 & .27 & .18 \\
\hline 12 & .07 & .17 & .80 \\
\hline 13 & .34 & .74 & .09 \\
\hline 14 & .78 & .23 & .20 \\
\hline
\end{tabular}

Note. FCSQ-14 - Flexibility in Coping with Stress Questionnaire; factors included in the subscale loadings are in boldface.

( $n=1093)$, somatically ill patients $(n=318)$ and alcohol addicts $(n=114)$. Pearson correlation coefficients obtained for the non-clinical group indicate strong correlations between Changeability and Repertoire $(r=.77, p<.001)$, and Changeability and Reflexivity $(r=.65, p<.001)$. Reflexivity, on the other hand, was found to be correlated with Repertoire at a moderate level $(r=.47, p<.001)$.

In the group of somatically ill patients, in comparison to healthy controls, the individual dimensions of flexibility correlated at a higher level. The strongest 
Figure 1

Factor structure of the FCSQ-14 $(N=1093)$

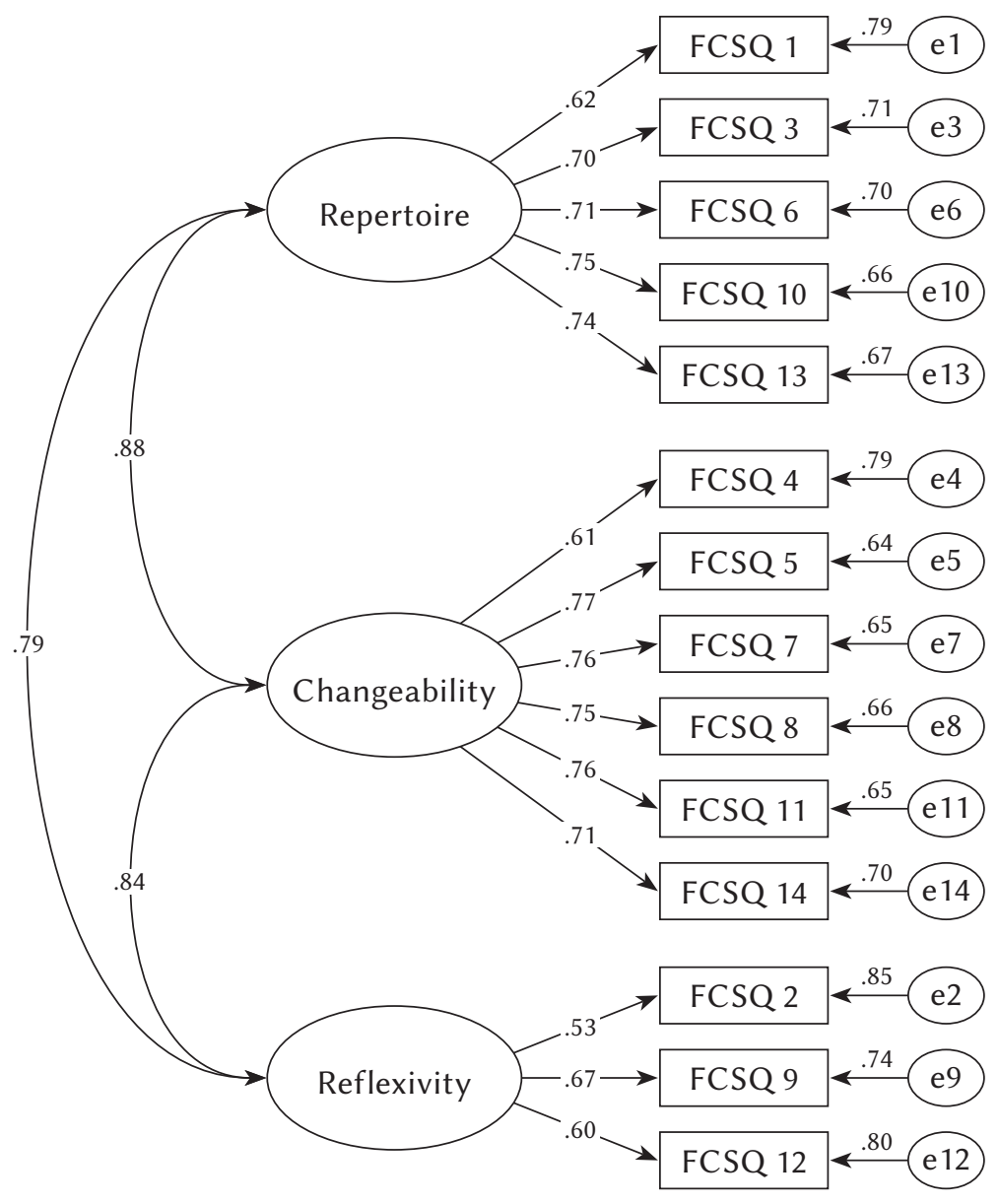

correlation was observed between Repertoire and Changeability $(r=.87, p<.001)$, while slightly weaker, but still strong, correlations were noted between Reflexivity and Changeability $(r=.78, p<.001)$ and between Reflexivity and Repertoire $(r=.68, p<.001)$. Similar correlation coefficients were also recorded in the group of alcohol addicts - correlation coefficients for the above-mentioned pairs were $.85(p<.001), .79$ $(p<.001)$ and $.74(p<.001)$, respectively. The obtained results show that in the group of healthy controls, the dimensions of flexibility in coping are more independent of one another. These findings give some grounds to interpret the overall result (in most of the existing tests the authors interpret only the subscales).

Analysis of intergroup differences in mean results of FCSQ-14. Intergroup comparisons were limited to exploring differences in flexibility in coping and its individual aspects based on the gender and age of healthy adults. The results of the analyses (Table 6) showed that women and men differ significantly from one another in two subscales of flexibility: men have a wider repertoire of coping strategies, while women show a higher degree of reflexivity. However, the effect sizes for the observed differences are small ${ }^{6}$.
An analysis using Pearson correlation coefficients showed statistically significant weak negative correlations between the age of the respondents, flexibility in coping and two subscales: Repertoire and Changeability. The younger the respondents were, the more flexible in coping they were $(r=-.08, p=.010)$, with a higher degree of changeability $(r=-.11, p<.001)$ and a wider repertoire of coping strategies $(r=-.10$, $p=.001)$.

In conclusion, the intergroup comparisons demonstrated that the FCSQ-14 is a tool which allows the detection of differences in the range of characteristics measured by it, due to the non-test criterion, which indicates its usefulness in scholarly research.

External validity. The external (convergent) validity of the FCSQ-14 was examined by comparing the results obtained with this tool with the results of the Cognitive Flexibility Inventory (CFI).

An analysis of the correlation between FCSQ-14 and CFI results was carried out in five subgroups: gastric patients $(n=98)$, alcohol addicts $(n=114)$, nurses $(n=271)$ and firefighters $(n=117)$, as well as healthy adults $(n=540)$. Pearson correlation coefficients are presented in Tables 7 and 8. 
Table 6

Sex differences in flexibility in coping in healthy subjects - Student's t-test results $(N=1093)$

\begin{tabular}{|c|c|c|c|c|c|c|c|}
\hline \multirow[t]{2}{*}{$\begin{array}{l}\text { FCSQ-14 } \\
\text { subscales }\end{array}$} & \multicolumn{2}{|c|}{$\begin{array}{l}\text { Women } \\
(n=791)\end{array}$} & \multicolumn{2}{|c|}{$\begin{array}{c}\text { Men } \\
(n=302)\end{array}$} & \multicolumn{3}{|c|}{ Differences } \\
\hline & M & $S D$ & M & $S D$ & $t$ & $p$ & $d$ \\
\hline Repertoire & 8.22 & 2.95 & 8.99 & 3.11 & 3.79 & $<.001$ & .25 \\
\hline Changeability & 10.57 & 3.68 & 10.57 & 3.77 & 0.00 & .996 & \\
\hline Reflexivity & 5.46 & 1.78 & 4.94 & 1.83 & -4.26 & $<.001$ & .29 \\
\hline Flexibility in coping (general result) & 24.26 & 7.51 & 24.50 & 7.64 & 0.49 & .627 & \\
\hline
\end{tabular}

Note. FCSQ-14 - Flexibility in Coping with Stress Questionnaire; $t$-value of the t-test statistic; $d$-Cohen's measure of sample effect size for comparing two sample means.

Table 7

Correlation coefficients between the FCSQ-14 and CFI results in the clinical groups

\begin{tabular}{lccc}
\hline Group of gastric patients $(n=98)$ & Control subscale & Alternatives subscale & Cognitive flexibility \\
\hline Repertoire & $.36^{* * *}$ & $.41^{* * *}$ & $.47^{* * *}$ \\
Changeability & $.31^{* *}$ & $.36^{* * *}$ & $.42^{* * *}$ \\
Reflexivity & .14 & $.38^{* * *}$ & $.34^{* * *}$ \\
Flexibility in coping (general result) & $.32^{* * *}$ & $.43^{* * *}$ & $.47^{* * *}$ \\
\hline Group of alcohol addicts $(n=114)$ & Control subscale & Alternatives subscale & Cognitive flexibility \\
\hline Repertoire & $.41^{* * *}$ & $.33^{* * *}$ & $.43^{* * *}$ \\
Changeability & $.33^{* * *}$ & $.31^{* * *}$ & $.37^{* * *}$ \\
Reflexivity & .18 & $.26^{* *}$ & $.26^{* *}$ \\
Flexibility in coping (general result) & $.35^{* * *}$ & $.33^{* * *}$ & $.39^{* * *}$ \\
\hline Note. FCSQ-14 - Flexibility in Coping with Stress Questionnaire; CFI - Cognitive Flexibility Inventory; ${ }^{* *} p<.01,{ }^{* * *} p<.001$.
\end{tabular}

The obtained values of Pearson correlation coefficients in individual samples confirm the external (convergent) validity of the FCSQ-14. The Repertoire and Changeability subscales correlated with the CFI at a moderate or high level. The Repertoire subscale proved to be the strongest correlate with cognitive flexibility, and the Reflexivity subscale showed the weakest correlation, which was a partly surprising result in the context of the theoretical assumptions. Nevertheless, this result may be the consequence of reduced reliability of the Reflexivity subscale. In addition, it was noted that the relationships between the FCSQ-14 and cognitive flexibility measured using the CFI are slightly less pronounced in clinical groups as compared to healthy subjects.

\section{NORMALIZATION}

Temporary norms (Table 9) were established for the group of healthy controls $(n=958)$, which included
275 men and 683 women with a mean age of 34.37 $(S D=11.50$, between 21 and 70$)$. Due to the slight differences in the presented construct by gender and age, common sten scores were established.

\section{THE ENGLISH-LANGUAGE VERSION OF THE FCSQ-14}

The concept construct of flexibility in coping is relatively new and less known to researchers from western cultures. So far, most studies on flexibility have been conducted in Asia (Cheng, 2001; Kato, 2001, 2012, 2015), and the tools for its measurement have not been reflected in Polish, American and Australian studies (Basińska, 2015; Jones, 2015; Southward, 2014). This fact was one of the reasons for undertaking efforts aimed at the development of our own tool, which would adequately represent all aspects of flexibility addressed in the field literature. Due to the unavailability of a tool for measuring flexibility 
Table 8

Correlation coefficients between the FCSQ-14 and CFI results in the group of nurses, firemen $(n=388)$ and in the group of healthy adults $(n=540)$

\begin{tabular}{|c|c|c|c|}
\hline FCSQ-14 & Control subscale & Alternatives subscale & Cognitive flexibility \\
\hline \multicolumn{4}{|c|}{ Nurses } \\
\hline Repertoire & $.36^{* * *}$ & $.37^{* * *}$ & $.41^{* * *}$ \\
\hline Changeability & $.25^{* * *}$ & $.36^{* * *}$ & $.38^{* * *}$ \\
\hline Reflexivity & $.12^{*}$ & $.29^{* * *}$ & $.26^{* * *}$ \\
\hline Flexibility in coping (general result) & $.27^{* * *}$ & $.39^{* * *}$ & $.41^{* * *}$ \\
\hline \multicolumn{4}{|c|}{ Firemen } \\
\hline Repertoire & $.63^{* * *}$ & $.49^{* * *}$ & $.64^{* * *}$ \\
\hline Changeability & $.46^{* * *}$ & $.44^{* * *}$ & $.53^{* * *}$ \\
\hline Reflexivity & $.28^{* *}$ & $.29^{* * *}$ & $.34^{* * *}$ \\
\hline Flexibility in coping (general result) & $.56^{* * *}$ & $.50^{* * *}$ & $.61^{* * *}$ \\
\hline \multicolumn{4}{|c|}{ Healthy adults } \\
\hline Repertoire & $.49^{* * *}$ & $.42^{* * *}$ & $.54^{* * *}$ \\
\hline Changeability & $.36^{* * *}$ & $.45^{* * *}$ & $.49^{* * *}$ \\
\hline Reflexivity & $.13^{* *}$ & $.34^{* * *}$ & $.30^{* * *}$ \\
\hline Flexibility in coping (general result) & $.40^{* * *}$ & $.47^{* * *}$ & $.52^{* * *}$ \\
\hline
\end{tabular}

Table 9

Temporary norms for healthy people for FCSQ-14 $(N=958)$

\begin{tabular}{|c|c|c|c|c|c|c|c|}
\hline \multicolumn{2}{|c|}{ FCSQ-14 general result } & \multicolumn{2}{|c|}{ Repertoire subscale } & \multicolumn{2}{|c|}{ Changeability subscale } & \multicolumn{2}{|c|}{ Reflexivity subscale } \\
\hline Raw score & Sten score & Raw score & Sten score & Raw score & Sten score & Raw score & Sten score \\
\hline $1-9$ & 1 & $0-1$ & 1 & $0-2$ & 1 & $0-1$ & 1 \\
\hline $10-12$ & 2 & $2-3$ & 2 & $3-4$ & 2 & 2 & 2 \\
\hline $13-16$ & 3 & 4 & 3 & $5-6$ & 3 & - & 3 \\
\hline $17-19$ & 4 & $5-6$ & 4 & $7-8$ & 4 & 3 & 4 \\
\hline $20-24$ & 5 & 7 & 5 & $9-10$ & 5 & 4 & 5 \\
\hline $25-27$ & 6 & $8-9$ & 6 & 11 & 6 & 5 & 6 \\
\hline $28-31$ & 7 & $10-11$ & 7 & $12-13$ & 7 & 6 & 7 \\
\hline $32-35$ & 8 & 12 & 8 & $14-16$ & 8 & 7 & 8 \\
\hline $36-38$ & 9 & $13-14$ & 9 & 17 & 9 & 8 & 9 \\
\hline $39-42$ & 10 & 15 & 10 & 18 & 10 & 9 & 10 \\
\hline
\end{tabular}

Note. FCSQ-14 - Flexibility in Coping with Stress Questionnaire.

in dealing with stress (not only in Poland, but also in most European countries), the English version of the FCSQ-14 became the focus of intensive research work. In order to complete this objective, a research team of 4 psychologists, proficient in English, per- formed a parallel translation of the FCSQ-14, and then one language version was agreed upon. A back translation of the inventory was made by a native speaker of English. In the next step, the research team made a critical, qualitative analysis of the trans- 
Table 10

Correlation coefficients between Polish and English versions of FCSQ-14 $(N=68)$

\begin{tabular}{lcccc}
\hline Versions & Repertoire (ENG) & Changeability (ENG) & Reflexivity (ENG) & FC (ENG) \\
\hline Repertoire (PL) & .93 & & & \\
Changeability (PL) & & .96 & & \\
Reflexivity (PL) & & & .85 & .96 \\
FC (PL) & & & \\
\hline
\end{tabular}

Note. FCSQ-14 - Flexibility in Coping with Stress Questionnaire; FC - flexibility in coping (general result); all correlations with a significance of $p<.001 ; \mathrm{PL}$ - subscales in Polish version; ENG - subscales in English version.

lated items and introduced minor language adjustments for several items.

With a view to initial assessment of the equivalence of the Polish and English versions of the FCSQ-14, the research was carried out using both language versions and a buffer test. A total of $68 \mathrm{flu}-$ ent speakers of English (22 men, 46 women), age range: $23-38\left(M_{\text {age }}=29.59, S D=3.91\right)$ were surveyed. The means and variances of the two versions did not differ significantly. Correlation coefficients between the two language versions are presented in the table below (Table 10, Appendices 1 and 2).

The correlation coefficients obtained for identical subscales are high and amount to .85 for Reflexivity, .93 for Repertoire and .96 for Changeability and the overall result. These preliminary analyses suggest that both language versions are equivalent. Nevertheless, the full procedure for determining the equivalence of the measurements made using the Polish and English versions should be implemented in the near future by conducting cross-cultural studies.

Additionally, we decided to estimate the external validity of the English version of the FCSQ-14 by analysing the correlation with COFLEX. The results indicate the convergence of both constructs; however, the high values of correlation coefficients suggest their relative independence. The Pearson correlation coefficient for the relationship between Changeability and Repertoire was .75 $(p<.001)$ and that for the relationship between Reflective coping and Reflexivity was $.57(p<.001)$. The overall result of COFLEX correlated with the overall result of the FCSQ-14 at $.82(p<.001)$

\section{DISCUSSION}

This study shows the structure and psychometric properties of a useful exploratory tool composed of a 14-item questionnaire enabling the investigation of flexibility in coping and three of its subscales: the Repertoire of coping strategies, the Changeability of their use and Reflexivity. The questionnaire applies to the study of healthy and ill adults, persons exposed to severe or chronic stress at work, when we want to assess their ability to change their functioning in a stressful situation. This article presents the aggregate results of somatically ill patients, high-risk professionals, healthy adults, and an additional combination of the latter two non-clinical groups.

In all the groups Cronbach's $\alpha$ for the overall result was high, and for subscales showed satisfactory reliability. For the Reflexivity subscale, relatively satisfactory values of Cronbach's $\alpha$ were recorded in the group of somatically ill persons and alcohol addicts. In the group of healthy controls and in the group of high-risk professionals, these values were lower. The lower values of internal consistency for this subscale, as compared to other subscales, can be explained by the fact that it comprises only three items ${ }^{7}$. Moreover, in non-clinical groups, the lower consistency of the Reflexivity subscale results from a poorer correlation of item 2 with other items. In clinical trials, the discriminating power of individual Reflexivity items is higher, suggesting that this dimension in flexibility in coping is particularly differentiating in difficult situations related to chronic stress. Nevertheless, any conclusion about the Reflexivity level should be drawn with caution in the study of healthy subjects, especially when it is an element of the individual's assessment.

The moderate correlation between the Changeability and Reflexivity subscales suggests that these dimensions of flexibility in coping might vary more over time (compared to the overall range of coping strategies available to the individual) and may depend on situational factors (Piórowski et al., 2017). The relatively low correlation coefficient obtained for the Reflexivity subscale may also result from its low internal consistency.

The resulting FCSQ-14 factor structure corresponds to the coping flexibility dimensions identified on the basis of theoretical assumptions. However, results of the psychometric analysis showed that aspects of flexibility, i.e., intra-situational and inter-situational changeability, should be considered together 
as the ability to change coping strategies to fit the situation and stress transaction.

The study shows strong correlations between Changeability and Repertoire, and Changeability and Reflexivity. Reflexivity, on the other hand, was found to be correlated with Repertoire at a moderate level. This is consistent with theoretical assumptions: a person with a broad repertoire will find it easier to change strategies because of their availability, and if they are reflective, they will be more willing to adjust their actions, which will be manifested in changes in the adopted strategies.

The FCSQ-14, like any other method, has certain limitations. Conclusions should be drawn carefully on the basis of the results obtained in the scale of Reflexivity, especially among healthy subjects. It should be remembered that the questionnaire is characterized by relatively low stability over time, which limits the predictions. The separate subscales differ in terms of consistency. The Repertoire subscale seems to indicate a more permanent property and belief of the individual that they are able to cope with stress, and the subscales of Changeability and Reflectivity will probably be more susceptible to modification by situational factors.

\section{CONCLUSIONS}

The Flexibility in Coping with Stress Questionnaire measures flexibility as a feature of the process of coping with which an individual applies coping strategies. The method is an accurate and reliable method of measuring coping flexibility and three of its subscales: the Repertoire of coping strategies, the Changeability of their use and Reflexivity. However, the results obtained on the Reflexivity scale in the non-clinical group should be interpreted with caution. Initial analyses suggest the equivalence of the Polish and English versions of the FCSQ-14. More detailed research is needed.

The FCSQ-14 is used for examining healthy subjects and persons suffering from diseases. The method can be used in scholarly research, however, during the individual's assessment.

\section{ENDNOTES}

1 Eigenvalues were higher than 1 (Kaiser's criterion). 2 Young people were also included in the study, but the results of those analyses were presented elsewhere.

3 One of the limitations reported in relation to Cronbach's $\alpha$ as a measure of reliability is its dependence on the number of items (Hornowska, 2001). A large number of similar items is associated with an increase in the coefficient (homogeneity of scale).
4 The statistical significance level recorded for the $\chi^{2}$ test indicates a mismatch between the model and the data due to the large sample size $-\chi^{2}$ statistics are sensitive to the sample size, resulting in the rejection of adequate models.

5 Due to the under-representation of individuals in specific clinical groups (gastric, cancer and cardiac patients and alcohol addicts), it was decided to carry out CFA in all subgroups together. In the future, however, it is worth expanding the scope of the study in order to test the fit of the model in homogeneous clinical groups.

6 Since the observed differences are slight, the standards for the whole group have been set, with no division by gender.

7 One of the limitations reported in relation to Cronbach's $\alpha$ as a measure of reliability is its dependence on the number of items (Hornowska, 2001). A large number of similar items is associated with an increase in the coefficient (homogeneity of scale).

\section{REFERENCES}

Basińska, M. A. (2015). Polish version of Coping Flexibility Scale - the summary of research results. In M. A. Basińska (Ed.), Coping flexibility with stress in health and in disease (pp. 273-294). Wydawnictwo UKW.

Basińska, M. A., Woźniewicz, A., \& Warchoł, Ł. (2015). Psychological resources and flexibility coping in patients with chronic disorders In M. A. Basińska (Ed.), Coping flexibility with stress in health and in disease (pp. 197-215). Wydawnictwo UKW.

Bonanno, G. A., Pat-Horenczyk, R., \& Noll, J. (2011). Coping flexibility and trauma: The Perceived Ability to Cope with Trauma (PACT) scale. Psychological Trauma: Theory, Research, Practice, and Policy, 3, 117-129. https://doi.org/10.1037/a0020921

Brandtstädter, J., \& Renner, G. (1990). Tenacious goal pursuit and flexible goal adjustment: Explication and age-related analysis of assimilative and accommodative strategies of coping. Psychology and Aging, 5, 58-67. https://doi.org/10.1037//08827974.5.1.58

Cheng, C. (2001). Assessing coping flexibility in real-life and laboratory settings: a multimethod approach. Journal of Personality and Social Psychology, 80, 814-833. https://doi.org/10.1037//00223514.80.5.814

Cheng, C. (2003). Cognitive and motivational processes underlying coping flexibility: a dual-process model. Journal of Personality and Social Psychology, 84, 425-438. https://doi.org/10.1037/0022-3514.84.2.425

Cheng, C., Hui, W., \& Lam, S. (1999). Coping style of individuals with functional dyspepsia. Psychosomatic Medicine, 61, 789-795. https://doi.org/ 10.1097/00006842-199911000-00011 
Cheng, C., Lau, H. P. B., \& Chan, M. P. S. (2014). Coping flexibility and psychological adjustment to stressful life changes: a meta-analytic review. Psychological Bulletin, 140, 1582-1607. https://doi. org/10.1037/a0037913

Dennis, J. P., \& Vander Wal, J. S. (2010). The Cognitive Flexibility Inventory: Instrument development and estimates of reliability and validity. Cognitive Therapy and Research, 34, 241-253. https://doi. org/10.1007/s10608-009-9276-4

Folkman, S., \& Lazarus, R. S. (1980). An analysis of coping in a middle-aged community sample. Journal of Health and Social Behavior, 21, 219-239. https://doi.org/10.2307/2136617

Grzankowska, I., Kruczek, A., Sołtys, M., \& Basińska, M. A. (2019). Kwestionariusz Elastyczności w Radzeniu Sobie ze Stresem dla Adolescentów (KERS-14A) [Flexibility of Coping with Stress Questionnaire for Adolescents (FCSQ-14A)]. Psychologia Rozwojowa, 24, 39-56.

Grzankowska, I., \& Minda, M. (2015). Self-esteem and coping flexibility in groups of college students and high school students. In M. A. Basińska (Ed.), Coping flexibility with stress in health and in disease (pp. 57-94 ). Wydawnictwo UKW.

Henselman, I., Fleer, J., Van Sonderen, E., Smink, A., Sanderman, R., \& Ranchor, A. V. (2011). The tenacious goal pursuit and flexible goal adjustment scales: a validation study. Psychology and Aging, 26, 174-180. https://doi.org/10.1037/a0021536

Hornowska, E. (2001). Testy psychologiczne. Teoria i praktyka [Psychological tests. Theory and practice]. Wydawnictwo Naukowe Scholar.

Janicka, M. (2015). Personal resources and coping flexibility with stress among a group of students. In M. A. Basińska (Ed.), Coping flexibility with stress in health and in disease (pp. 133-157). Wydawnictwo UKW.

Jankowski, K. S., \& Zajenkowski, M. (2009). Metody szacowania rzetelności pomiaru testem [Methods of estimating the reliability of test measurement]. In K. Fronczyk (Ed.), Psychometria - podstawowe zagadnienia [Psychometry - basic issues] (pp. 84110). Vizja Press \& IT.

Jones, D. R. (2015). Living in the moment: Daily life assessments of mindfulness meditation on stress, coping flexibility, and well-being (Master thesis). Western Washington University. Retrieved from https://cedar.wwu.edu/wwuet/422/

Kato, T. (2001). The relationship between flexibility of coping to stress and depression. Japanese Journal of Psychology, 72, 57-63. https://doi.org/10.4992/ jjpsy. 72.57

Kato, T. (2012). Development of the Coping Flexibility Scale: Evidence for the coping flexibility hypothesis. Journal of Counseling Psychology, 59, 262-289. https://doi.org/10.1037/a0027770
Kato, T. (2014). Effects of flexibility in coping with chronic headaches on depressive symptoms. International Journal of Behavioral Medicine, 22, 506511. https://doi.org/10.1007/s12529-014-9443-1

Kato, T. (2015). The dual-process theory: New approach to coping flexibility. In M. A. Basińska (Ed.), Coping flexibility with stress in health and in disease (pp. 19-37). Wydawnictwo UKW.

Kruczek, A. (2015). Emotion control and anger expression style in relation to coping flexibility in students of middle and secondary schools. In M. A. Basińska (Ed.), Coping flexibility with stress in health and in disease (pp. 95-116). Wydawnictwo UKW.

Lazarus, R. S. (1993). Coping theory and research: Past, present, and future. Psychosomatic Medicine, 55, 234-247. https://doi.org/10.1097/00006842-199305 000-00002

Lazarus, R. S., \& Folkman, S. (1984). Stress, appraisal, and coping. Springer.

Peng, K., \& Nisbett, R. E. (1999). Culture, dialectics, and reasoning about contradiction. American Psychologist, 54, 741-754. https://doi.org/10.1037/0003066X.54.9.741

Piórowska, A., \& Banasik, A. (2015). Coping flexibility and hope in police officers' group. In M. A. Basińska (Ed.), Coping flexibility with stress in health and in disease (pp. 175-193). Wydawnictwo UKW.

Piórowski, K., Basińska, M. A., Piórowska, A., \& Grzankowska, I. (2017). Adaptation of the Cognitive Flexibility Inventory. Przeglad Psychologiczny, 60, 605-620.

Schumacker, R. E., \& Lomax, R. G. (2004). A beginner's guide to structural equation modeling (Second edition). Lawrence Erlbaum Associates Publishers.

Sołtys, M. (2015). Cultural adaptation and psychometric properties of the Coping Flexibility Scale: Current results of polish studies. In M. A. Basińska (Ed.), Coping flexibility with stress in health and in disease (pp. 38-54). Wydawnictwo UKW.

Southward, M. W. (2014). The impact of expressive flexibility and context sensitivity on distress (Master thesis). Ohio State University. Retrieved from http://rave.ohiolink.edu/etdc/view?acc_num =osu 1413288630

Vowles, K. E., McCracken, L. M., Sowden, G., \& Ashworth, J. (2014). Psychological flexibility in coping with chronic pain: Further examination of the Brief Pain Coping Inventory-2. The Clinical Journal of Pain, 30, 324-330. https://doi.org/10.1097/ AJP.0b013e31829ea187

Vriezekolk, J. E., van Lankveld, W. G., Eijsbouts, A. M., van Helmond, T., Geenen, R., \& van den Ende, C. H. (2012). The coping flexibility questionnaire: Development and initial validation in patients with chronic rheumatic diseases. Rheumatology International, 32, 2383-2391. https://doi.org/10.1007/ s00296-011-1975-y 
APPENDIX 1

\section{ENGLISH VERSION OF FLEXIBILITY IN COPING WITH STRESS QUESTIONNAIRE}

People often face difficult or stressful situations in their life. They can't always realize their desires and goals as they wish. Every person tries to deal with such situations in their own way and uses different ways of acting and thinking. The following statements describe approaches to coping with stress. Please, read each one carefully. Point to what extent each one of them applies to you - choose one of the following for each statement:

0 - never applies

1 - sometimes applies

2 - often applies

3 - always applies

\begin{tabular}{l}
\hline Statements \\
\hline 1. I see many various solutions in a stressful situation. \\
2. If I am not able to change my situation, I try to accept it. \\
3. Depending on the problem, I use a many different methods to cope with stress. \\
4. I can change my way of coping, if it seems to be ineffective in a given situation. \\
5. I try different ways to manage stress until I succeed. \\
6. Regardless of the situation, I know what to do to cope with stress. \\
7. I change the way of coping with stress if my situation does not improve. \\
8. I look for the most effective ways of managing stress. \\
9. In a stressful situation, I ask myself what is really important for me. \\
10. I am able to find adequate ways of coping with stress in every situation. \\
11. If I cope with stress ineffectively, I change my behaviour. \\
12. I give myself time to think how to cope when I am in a difficult situation. \\
13. Even if new difficulties appear, I know how to change my actions to cope with them. \\
14. When I cannot manage a difficult situation, I change my approach.
\end{tabular}




\section{KWESTIONARIUSZ ELASTYCZNOŚCI W RADZENIU SOBIE ZE STRESEM}

Płeć Wiek Wykształcenie Stan cywilny

Ludzie napotykają w swoim życiu trudne lub stresujące sytuacje, a ich pragnienia i cele nie zawsze mogą być zrealizowane tak, jakby sobie tego życzyli. Każdy człowiek na swój sposób próbuje radzić sobie z takimi sytuacjami, stosując różne sposoby działania i myślenia. Poniższe twierdzenia opisują podejścia do radzenia sobie ze stresem. Przeczytaj proszę każde z nich uważnie. Wskaż, w jakim stopniu każde z nich dotyczy Ciebie, wybierając dla każdego stwierdzenia jedną z następujących odpowiedzi:

0 - nigdy nie dotyczy

1 - czasami dotyczy

2 - często dotyczy

3 - zawsze dotyczy

Twierdzenia $\quad \begin{array}{llll}0 & 1 & 2 & 3\end{array}$

1. W stresującej sytuacji widzę wiele różnych rozwiązań.

2. Jeśli nie jestem w stanie zmienić swojej sytuacji, staram się ją zaakceptować.

3. Wykorzystuję wiele różnych metod radzenia sobie ze stresem w zależności od problemu.

4. Potrafię zmienić swój sposób radzenia sobie, jeśli w danej sytuacji wydaje mi się nieskuteczny.

5. Wypróbowuję różne sposoby poradzenia sobie ze stresem, aż mi się uda.

6. Niezależnie od sytuacji wiem, co zrobić, by poradzić sobie ze stresem.

7. Zmieniam sposób radzenia sobie ze stresem, jeśli moja sytuacja nie ulega poprawie.

8. Szukam sposobów, żeby jak najskuteczniej poradzić sobie ze stresem.

9. W stresującej sytuacji pytam siebie, co jest dla mnie naprawdę ważne.

10. W każdej sytuacji jestem w stanie znaleźć odpowiednie sposoby radzenia sobie ze stresem.

11. Zmieniam postępowanie, gdy nieskutecznie radzę sobie ze stresem.

12. W trudnej sytuacji daję sobie czas, aby zastanowić się, jak sobie poradzić.

13. Nawet jeśli pojawią się nowe trudności, będę wiedział, jak zmienić swoje działania, by poradzić sobie.

14. Gdy nie radzę sobie w trudnej sytuacji, zmieniam swoje podejście. 